\title{
국제개발협력 평가 동향과 협력단의 과제
}

\author{
차 은 주 $\mathrm{KOICA}$ 사업평가실 과장
}

목차
I. 서론
II. 개발협력에서 평가의 진화
III. OECD/DAC에서의 평가 논의
IV.주요 선진국들의 평가 동향
V. 협력단의 평가현황 및 과제

\section{I. 서론}

21세기에 접어들면서 개발협력 관련 논의는 새천년개발목표(Millennium Development Goals, $\mathrm{MDGs}$ ) 달성, 원조효과성을 위한 파리선언 이행 등을 중심으로 이뤄지고 있다. MDGs는 '경제성장 및 사회기반시설 확충이 빈곤감소에 기여한다(trickle-down effect)'는 개발협력의 기존 관점이 아 닌 빈곤문제 자체를 대상으로 하는(targeting) 개발협력의 필요성에 대한 인식을 높였으며, 파리선 언은 개발협력에서 수원국, 공여국 및 여타 이해관계자의 파트너십(주인의식, 원조일치, 원조조화 등)이 궁극적으로 원조효과성 증진에 기여한다는 공감대를 형성하고 있다.

$\mathrm{MDGs}$ 와 파리선언 등 최근 개발협력에 도입되는 새로운 목표 및 원칙에서 나타나는 공통점 중의 하나는 ‘목표 수립 $\rightarrow$ 지표설정 $\rightarrow$ 성과관리 및 모니터링’ 등 일련의 성과중심관리체계(Results Based Management, RBM)를 차용하고 있다는 점이다. MDGs는 빈곤감소 관련 8개의 목표 (Goals)를 수립하고 관련 지표(indicators)를 설정함으로써 개발파트너들이 이 지표를 중심으로 개 발협력사업을 추진하도록 하고 그 목표달성도를 측정하고 있다. 파리선언 역시 5 개의 원조효과성 원칙에 따른 12 개의 지표를 개발해 수원국 및 공여국을 대상으로 이행현황을 측정하고 있다. 개발 협력에서 이러한 흐름은 빈곤감소를 위한 수원국, 공여국, 그리고 여타 이해관계자들의 노력이 투 
입(input) 또는 일차적인 산출물(output) 수준에서만 점검되고 평가되는 것이 아니라 실제적인 결 과물(outcome) 및 영향력(impact)을 포함한 성과(Results)를 측정하려고 하는 개발협력 평가 동향 과 연관된다고 볼 수 있다.

원조를 포함한 공공분야에서 평가의 중요성은 새삼 강조할 필요가 없을 것이다. 하지만 지난 50 여 년의 해외개발원조 역사에서 평가의 필요성은 더욱 절실했는데, 이것은 공여기관들이 원거리에서 실시되는 개발협력사업의 성과를 평가해 국내외적으로 책임성을 확보하는데 많은 어려움을 겪었기 때문이다. 이러한 필요는 원조사업 평가와 관련한 다양한 방법론 및 도구의 발전을 가져왔다.

본 논문은 우선 개발협력에서 평가가 어떻게 진화해왔는지는 살펴보고, 최근 $\mathrm{OECD} / \mathrm{DAC}$ 및 선진 공여국 사이에서 활발하게 논의되고 있는 주요 평가 이슈를 짚어보도록 하겠다. 다음에 협력단의 평가현황 및 과제를 분석한 뒤 $\mathrm{OECD} / \mathrm{DAC}$ 가입국으로서 향후 협력단의 평가가 나아갈 방향을 논 의한다.

\section{II. 개발협력에서 평가의 진화}

개발도상국에 대한 선진국들의 원조사업은 1960 년대 전후로 본격화되었지만, 평가가 강조되기 시 작한 것은 이로부터 20 년 이상이 지난 이후부터였다. 1970 년대까지만 해도 별도의 평가부서를 가 진 원조기관은 거의 없었으며, 평가를 실시할 수 있는 전문인력이나 평가재원은 턱없이 부족했다. 추진된 평가 또한 사업이 종료된 이후에나 실시하는 것으로 인식되어 있었으며 사업설계 단계에서 의 평가기획 및 기준치조사(Baseline)를 포함한 사전조사 필요성에 대한 인식은 매우 낮았다.

그러나 1960-1970년대 추진된 원조사업의 효과성에 대한 회의가 공여국내에서 확산되면서 지속 적으로 증가하던 원조규모가 1980년대에 주춤하게 되자, 원조기관들은 기존에 추진되던 원조사업 을 개선함과 동시에 평가 강화를 통해 사업의 효과성을 입증해야 할 필요성에 직면하게 되었다. 이 에 따라 다양한 원조사업관리 및 평가방법이 개발되기 시작하였다.

1) Basil Edward Cracknell, Evaluating Development Aid: Issues, problems and solutions (Sage Publication India Pvt Ltd, 2000), pp. 40-44. 


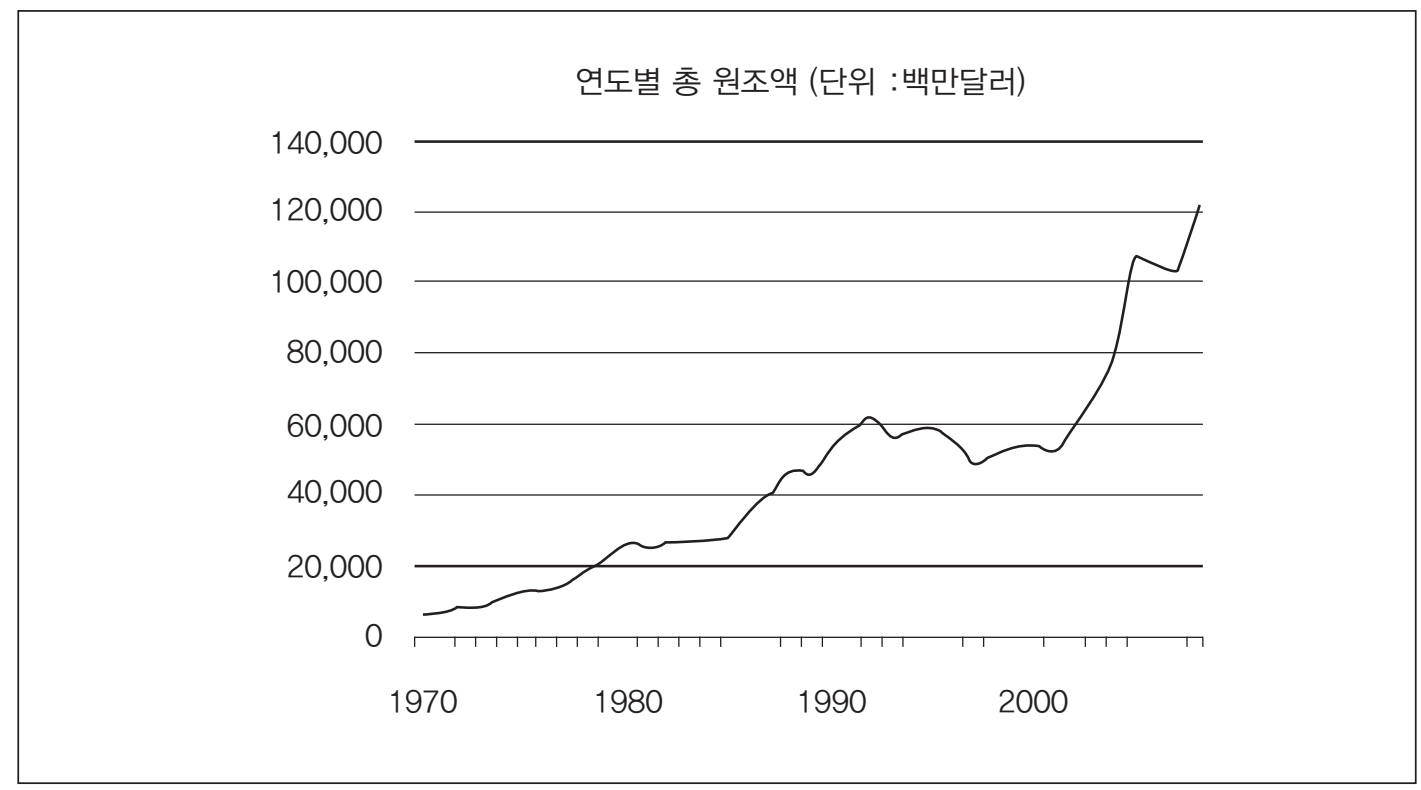

자료출처 : OECD 통계사이트 www.stats.oecd.org/qwids, (2010.5.1)

1980년대 원조사업 평가에서 가장 큰 변화는 논리모형(Logical Framework, Logframe)의 개념 이 원조사업 관리(Aid Management)에 본격적으로 도입된 것이다. ${ }^{2)}$ Logframe은 개발사업 설계 에 활용되는 도구로서, 사업의 투입, 산출, 결과물 등 주요 요소와, 이 요소들의 인과관계(Causal relationship), 지표, 위험요소들이 포함된다. ${ }^{3)}$ 따라서 Logframe의 도입은 기존의 원조사업에 비 해 더욱 체계적인 사업기획, 관리 및 평가를 가능하게 하였다.

1990년대는 냉전의 해체와 더불어 선진국들의 공여액이 전반적으로 감소했던 반면, 빈곤감소, 거 버넌스, 환경, 인권과 같은 다양한 이슈들이 개발협력에서 꽃피기 시작했다. 이에 따라 평가모형 및 방법도 다양한 이슈를 반영하는 방향으로 진화했는데, 기존의 Logframe 중심 평가에서 이해관계 자 분석(Stakeholders analysis) 및 참여적 접근방법(Participatory approach)이 강조되기 시작했 다. 아울러 개발협력 전반에서 공여국 및 수원국 간 파트너십이 강조되면서 기존의 공여국 주도 평 가에서 수원국이 참여하고 수원국의 평가역량을 활용할 수 있는 평가가 확산되기 시작하였다.

2) Cracknell (2000), pp. 44-47.

3) Jody Zall Kusek and Ray C. Rist. Ten Steps to a Results-Based Monitoring and Evaluation System ( The World Bank, 2004), Annex VI. 


\section{OECD/DAC에서의 평가 논의}

\section{1. 평가원칙}

OECD 개발협력위원회(Development Assistance Committee, DAC)는 원조관련 다양한 이슈가 논의되는 공여국간 모임으로서, 개발협력 평가 강화를 위한 다양한 논의도 이뤼지고 있다. DAC 은 지속적인 연구조사를 통해 평가관련 각종 원칙 및 가이드라인을 제시해오고 있는데, 그 중 가 장 대표적인 것이 1991년 발간된 개발원조평가원칙(Principles for Evaluation of Development Assistance)이다. 이 원칙은 원조기관이 명확한 평가정책 및 제도를 구축하고, 독립적이고 투명한 평가를 실시하여 그 결과를 정책 및 사업에 반영(Feedback, 피드백)함으로써 원조 효과성을 제고 하도록 권고하고 있다.

\section{〈Box1〉DAC 개발원조평가원칙 주요내용}

- 원조기관은 명확한 평가정책, 가이드라인, 방법을 가지고 있어야 하며, 평가수행을 위한 조직 구조 및 제도적 절차를 갖추어야 한다.

· 평가과정은 정책결정 및 사업수행과정으로부터 독립적이어야 한다.

· 평가과정은 가능한 공개되어 그 결과가 쉽게 이용되어야 한다.

· 평가결과를 정책결정자 및 사업수행자들에게 피드백함으로써 평가유용성을 강화해야 한다.

· 원조평가에서 수원국 및 여타 공여국과의 파트너십은 중요하다. 이러한 파트너십은 수원국의 제도적 발전 및 행정적 부담을 경감한다.

· 원조평가는 원조사업 기획단계부터 필수적 요소로 포함되어야 한다. 사업의 명백한 목표를 확 립하는 것은 객관적 평가의 전제조건이다.

이와 더불어 $\mathrm{DAC}$ 은 회원국 대상 정기적으로 실시하는 동료검토(Peer Review) ${ }^{4)}$ 에서 원조기관의 평가기능 검토를 강화할 수 있도록 평가시스템 및 사용현황 평가툴(Evaluation Systems and Use : a Working Tool for Peer Reviews and Assessments)을 발간했다. 이 평가툴은 앞서 평가원칙 에서 강조된 명확한 평가정책 수립 및 평가의 독립성 확보와 더불어, 적절한 수준의 평가재원 및 인 력 배분, 평가의 질(Quality) 확보 시스템 수립, 다년간 평가계획의 수립, 평가결과의 활용을 위한 제도적 장치 수립 등을 통해 원조기관의 투명성과 책임성을 확보하도록 하고 있다.

4) DAC의 동료검토(Peer Review)는 DAC 회원국간 교차적으로 서로의 원조사업 및 수행체제를 모니터링 및 평가하는 것으 로서, 회원국들은 매 4년에 한 번씩 동료검토를 받고 있음 
아울러 $\mathrm{DAC}$ 은 개발협력 평가를 $\mathrm{DAC}$ 의 주요 역할로 인식하고, 산하 작업반인 개발평가네트워크 ((DAC Network on Development Evaluation, Evalunet)를 운영하며 회원국들과 지속적으로 개 발협력 평가 개선에 노력하고 있다.

\section{〈Box2〉 DAC 개발평가 네트워크 (Evalunet)}

$\mathrm{OECD/DAC} \mathrm{상에서의} \mathrm{평가논의는} \mathrm{1982년} \mathrm{원조평가를} \mathrm{위한} \mathrm{전문가그룹(Expert} \mathrm{Group} \mathrm{on} \mathrm{Aid}$ Evaluation)을 구성하면서 본격적으로 시작되었다. 이후 이 그룹은 DAC 원조평가를 위한 작업 반(DAC Working Party on Aid Evaluation)을 거쳐 2003년 3월부터 DAC 개발평가 네트워크 (Evalunet)로 개편되었다. Evalunet은 현재 DAC의 8개 산하작업반 중 하나로서 DAC 회원국 또는 회원기관의 평가담당자와 전문가들이 모여 평가경험을 공유하고 학습하며, 서로간 상이한 평가절 차 및 방법들을 조정하고, 새로운 평가 가이드라인 및 방법론을 개발하는 장이 되고 있다. 우리나 라는 2010.1월 DAC가입과 함께 Evalunet에 회원국 자격으로 참여하기 시작하였다.

\section{DAC Evalunet에서의 평가논의 동향}

Evalunet에서 현재 논의되는 주요 이슈는 1) 파리선언 이행현황 평가, 2) 공동평가, 3) 개발평가의 질적 기준, 4) 평가역량 강화, 5) 다자효과성 평가, 6) 분쟁방지 및 평화구축사업 평가, 7) 예산지원 사업 평가 등이다.

\section{1) 파리선언 이행현황 평가}

Evalunet은 현재 원조효과성을 위한 파리선언(Paris Declaration on Aid Effectiveness, 파리선 언) 이행현황 2 차 평가를 실시하고 있다. 평가는 DAC 원조효과성 작업반(Working Party on Aid Effectiveness)이 실시하는 파리선언 '모니터링'과 보완적인 작업으로서, 원조효과성작업반이 파리 선언 12개 지표의 이행현황만을 모니터링하고 있는데 반해, Evalunet은 이번 평가를 통해 파리선 언 이행결과에 따른 실질적인 성과와 영향력을 종합적으로 조사· 분석하게 된다.

파리선언 평가는 공여국, 수원국, 시민사회 대표들로 구성된 국제자문그룹(International Reference Group) 및 평가팀(Core Evaluation Team)을 통해서 추진되고 있으며, 사례조사에 참 여하는 수원국 및 공여국은 별도로 국내자문그룹 및 평가팀을 구성해 국별평가를 추진하고 있다. 평 가결과는 2011년 서울에서 개최되는 제4차 원조효과성 고위급회의(4th High Level Forum on Aid Effectiveness)에서 발표되어, 차후 원조효과성 및 개발효과성 논의의 기초자료로 활용될 예정이다. 


\section{2) 공동평가 (Joint evaluations)}

공동평가란 다수의 공여국이 참여하거나, 수원국과 공동으로 수행하는 평가를 의미한다. ${ }^{5)} \mathrm{DAC}$ 은 공여국이 개별적으로 실시하는 수많은 평가로 인해 수원국의 행정적 부담 및 비용이 증가하고 있다 고 파악하고, 이것을 방지하는 차원에서 공동평가를 장려하고 있다. Evalunet은 공여국간 상이한 평가기준 및 평가절차로 인해 공동평가 추진시 발생할 수 있는 문제를 방지하기 위한 공동평가가이 드라인(Guideline on Joint Evaluation)을 제시하고 있다. 아울러 Evalunet 홈페이지를 통해 회 원국의 연간 평가계획을 공유하도록 함으로써 서로간 공동평가의 기회를 모색하고, Evalunet 정기 회의에서 공동평가의 경험과 교훈을 공유하고 학습하도록 지원하고 있다.

대부분의 공동평가는 2 개 이상의 공여국 및 수원국이 참여하는 형태로 추진되지만, 예산지원사업 (Budget support)과 같이 다수의 국가 및 기관이 함께 지원한 사업에 대해서는 다수의 기관이 참 여하는 대규모 공동평가(Multi-donor, multi-partner evaluation)가 추진되기도 한다. 참고로, 공동평가 경험이 많은 공여국들은 공동평가가 가능한 사업(공동사업 및 프로그램형 원조 등)에 대 해 선별적으로 추진하는 것이 더욱 효과적이라고 제언하고 있다.

\section{3) 개발평가의 질적 기준 (Quality standards for development evaluations)}

개발협력 평가과정 및 평가보고서의 질(Quality of evaluation process and products) 또한 최근 주요 이슈로 Evalunet에서 논의되고 있다. 신뢰할만한 수준의 평가과정을 통해 도출된 결과 및 교 훈이 피드백됨으로써 궁극적으로 원조사업의 효과성을 증진할 수 있기 때문이다.

Evalunet은 2006년 DAC 개발평가질적기준(DAC Quality Standards for Development Evaluation) 초안을 발간하고 3년여의 시범기간을 거쳐 2010년 2월 회원국들로부터 승인을 받았 다. 이 '기준'은 평가 목표설정, 기획, 설계, 수행, 결과보고, 피드백 등 평가의 전 단계에서 평가의 질을 확보하기 위한 요건들을 제시하고 있으며, 원조기관간 평가시스템의 수준을 비교하는 기준으 로도 활용이 가능하다.

5) OECD/DAC, "Glossary of Key Terms in Evaluation and Results Based Management," http://www.oecd.org/docu ment/21/0,3343,en_2649_34435_40381973_1_1_1_1,00.html (검색일 2010년 5월 1일). 


\section{4) 평가역량 강화 (Evaluation capacity development)}

파리선언을 통해 수원국의 주인의식(Ownership) 및 원조일치(Alignment)가 강조됨에 따라, 공여 국들은 전략수립, 사업발굴, 사업기획, 사업수행, 조달 등 일련의 원조사업 수행 절차를 수원국의 시스템에 일치시키고, 수원국의 역량을 최대한 활용하고자 노력하고 있다. 평가 또한 파리선언의 원칙에 입각해 수원국의 평가역량을 활용하고 평가역량을 길러줄 수 있는 방향으로 발전하고 있으 며, 평가역량의 강화는 다시 상호책임성 확보, 공동사업 추진의 기반 마련에 기여할 수 있다.

Evalunet은 조직의 주요 임무(Mandate) 중 하나로 ‘평가역량 강화 지원’을 포함하고, 그 중요성을 회원국들에게 지속적으로 강조해 왔으며, 회원국들의 경험공유를 장려하는 차원에서 평가역량강화 를 위한 정보집(Tip-sheet)을 제작중이다.

\section{5) 다자효과성 평가 (Evaluating multilateral effectiveness)}

다자효과성 평가는 기존에 상당한 양의 원조가 다자기구(UN산하기구, 개발은행 등)를 통해 지원되 고 있음에도 불구하고 그 효과성에 대한 정보가 부족(Information gap)하다는 인식에서 최근 새롭 게 강조되고 있다. 기존에 이미 다자기구별 자체평가 및 일부 공여국에 의한 개별적 평가가 추진되 고 있으나, 보다 객관적이고 종합적인 다자기구 평가의 필요성이 제기됨에 따라 최근 다자기구 평 가는 공여국, 수원국, 다자기구가 함께 참여하는 공동평가의 형태로 발전하고 있다. DAC은 2004년 부터 유엔평가그룹(United Nations Evaluation Group, UNEG)과 공동으로 UN산하기구의 평가 시스템에 대한 동료검토(Peer review)를 실시해오고 있으며, 이는 다자기구가 적정수준의 자체 평 가역량을 보유했을 경우 자체적으로 개발성과를 관리하고 평가할 수 있을 것이라는 가정에 기반한 다. 아울러 일부 공여국들은 다자기구성과평가네트워크(Multilateral Organization Performance Assessment Network, MOPAN)를 통해 다자효과성을 공동으로 평가하고 있다. 


\section{〈Box3〉 다자기구성과평가네트워크(MOPAN)}

16 개 공여국간 모임으로 2002년 설립되었으며 매년 3-4개의 다자기구를 선정하여 기관의 조직 적 효과성(Organizational Effectiveness)을 평가하고 있다. 평가범위는 대상기관의 전략관리, 사 업관리, 파트너쉽관리, 지식관리 등 네 가지이다. 당초 MOPAN은 공여국 및 수원국의 다자사업 담당자들에 대한 인식조사(Perception based survey)만을 평가방법론으로 활용하였으나, 최근 다자기구의 정책문서 검토(Document review)를 함께 수행하여 평가결과의 객관성을 높이고자 노 력하고 있다. 2010년도에는 ADB, WHO, UNFPA, IFAD에 대한 평가를 추진 중이며, 회원국으로는 호주, 오스트리아, 벨기에, 캐나다, 덴마크, 핀란드, 프랑스, 독일, 아일랜드, 네덜란드, 노르웨이, 스페인, 스웨덴, 스위스, 영국이 활동 중이고, 우리나라는 2008년 가입하였다.

아울러 최근 원조에서 개발효과성(Development Effectiveness)이 강조됨에 따라, 다자기구의 개 발효과성에 대한 평가 필요성도 제기되고 있다. Evalunet을 중심으로 공여국들은 다자사업 개발효 과성 평가를 추진 중이며, 기존의 접근법(MOPAN, $\mathrm{COMPAS}^{6)}, \mathrm{DAC} / \mathrm{UNEG}$ 동료심사 등)을 최대 한 활용하여 평가방법을 개발하고 있다.

\section{6) 분쟁방지 및 평화구축사업 평가}

전세계적으로 분쟁방지 및 평화구축사업이 계속 확대되고 있으며, 이러한 사업들은 사업관리 및 평 가에 더욱 세심한 노력이 요구된다. 그러나 실제로 분쟁방지 및 평화구축 사업에 대한 평가도구 및 가이드라인이 부족하다는 인식아래, Evalunet과 DAC 분쟁 및 취약국가 네트워크(Network on Conflict, and Fragility, INCAF)가 공동으로 관련 평가가이드라인을 개발하고 있다. DAC의 분쟁 방지 및 평화구축사업 평가 가이드라인은 콩고민주공화국, 아이티, 스리랑카, 수단 등 취약국가에 서 추진 중인 사업에 중요한 사업관리 및 평가도구로 활용될 수 있을 것이다.

\section{7) 예산지원사업 평가}

유럽 공여국들을 중심으로 개발도상국의 재정을 직접 지원하는 예산지원사업(Budget support) 이 증가함에 따라, 동 사업에 대한 효과성 평가에도 관심이 높아지고 있다. 예산지원사업은 특성 상 다수의 공여기관이 특정예산을 함께 지원하기 때문에 공동평가의 필요성이 높으며, 이에 따라 Evalunet을 중심으로 공여국들이 부르키나파소, 말라위, 모잠비크, 니카라과, 르완다, 우간다, 베

6) Common Performance Assessment System : 다자개발은행의 성과중심관리 역량 및 현황을 평가하는 자체평가 시스템 
트남의 일반예산 지원사업(General budget support) 공동평가를 2006년도에 시행하였다. 이 평 가는 예산지원사업에 대한 과정평가로서 '시행절차' 상의 적절성, 효율성, 효과성을 위주로 평가하였 으며, 현재 일부 공여국들은 예산지원사업의 '성과’를 측정하기 위한 평가방법론을 개발하고 있다.

\section{IV. 주요 선진국들의 평가 동향}

\section{1. 성과중심관리의 강화}

90년대 전후, 여타 공공분야와 마찬가지로 개발협력에도 가시적 성과에 대한 관심이 증가하면서, 원조기관에 성과중심관리(RBM) 체계가 도입되기 시작했다. ${ }^{7)} \mathrm{RBM}$ 이란 목표한 성과를 달성하기 위해 관련 조직에 동기를 부여하고, 필요한 절차 및 자원을 활용하는 관리시스템 전반을 의미한 다. ${ }^{8)}$ 구체적인 성과목표를 수립하는 것은 $\mathrm{RBM}$ 의 시작이자 가장 중요한 요소 중 하나다. 아울러 목 표는 측정가능하고 모니터링이 가능한 것이어야 하는데 “성과를 측정하지 않는다면, 성공인지 실패 인지 말할 수 없다(If you do not measure results, you cannot tell success from failure)” ${ }^{9)}$ 는 관점에서 강조되고 있다. $\mathrm{RBM}$ 에서는 일반적으로 성과가 투입-산출-결과 단위에서 지표로 설정되 어 관리 및 모니터링된다. 공여기관들은 $\mathrm{RBM}$ 을 통해 기존의 예산집행실적, 투입, 산출물을 관리하 고 평가하던 시스템에서 벗어나 빈곤감소 및 개발이라는 뚜렷한 성과를 목표로 운영되는 조직으로 발전해오고 있다.

7) OECD/DAC, "Results Based Management In The Development Cooperation Agencies: A Review of Experience," 2001년 DAC 원조평가작업반 회의의 background paper로 작성됨

8) 아시아개발은행의 정의를 따름 http://www.adb.org/projects/rbm/about.asp

9) Kusek and Rist (2004), pp.11. 
〈표1〉성과중심관리(RBM) 절차

\begin{tabular}{|c|c|c|}
\hline 단계 & 내용 & 사용가능 도구(틀) \\
\hline 1. 상황 분석 & 해당사업(또는 정책 및 이슈)에 대한 배경 및 상황을 분석함 & $\begin{array}{l}\text { Conceptual } \\
\text { Framework }\end{array}$ \\
\hline 2. 목표 설정 & \begin{tabular}{|l|} 
달성해야할 성과(Results) 중심으로 목표를 수립함 \\
(투입, 산출, 결과물, 영향력 등 다양한 수준에서 성과목표가 수립될 수 있음)
\end{tabular} & $\begin{array}{l}\text { Results Chain 또는 } \\
\text { Results Framework }\end{array}$ \\
\hline 3. 지표 설정 & 각각의 성과에 대해서 측정 가능한 지표 수립 & $\begin{array}{l}\text { Indicator Reference } \\
\text { Sheet }\end{array}$ \\
\hline $\begin{array}{l}\text { 4. 목표치 결정 및 } \\
\text { 기준치 조사 }\end{array}$ & $\begin{array}{l}\text { 성과를 판단하기 위해 개별 지표에 대한 명확한 목표치(target)를 결정하고 } \\
\text { 비교대상으로서 기준치(baseline)를 조사 }\end{array}$ & \\
\hline $\begin{array}{l}\text { 5. 자료수집 및 } \\
\text { 분석 }\end{array}$ & 지표 관련 데이터를 정기적으로 수집, 분석 및 보고 & \\
\hline 6. 결과 활용 & 모니터링 및 분석결과를 차후 의사결정 과정에 반영 & \\
\hline
\end{tabular}

자료출처 : KOICA의 '논리모형기획 및 성과중심관리 교육결과보고서(2008)' 및 World Bank의 'Ten Steps to a Result-Based Monitoring and Evaluation System(2004)'를 참고로 저자가 작성함

\section{2. 평가의 중요성 제고}

원조규모가 확대되고 원조기관의 책임성이 강조됨에 따라, 평가의 중요성 또한 높아지고 있다. 원 조기관들은 평가정책을 강화하고, 평가 매뉴얼 개발 및 직원교육을 확대해 조직의 평가역량을 강 화하고 있다. 아울러 평가의 객관성 확보를 위해 평가부서의 독립성이 강화되고 있는데, 2009년도 DAC Evalunet조사에 따르면 ${ }^{10)}$ 대부분의 원조기관에서 평가부서는 사업부서로부터 독립되어 있으 며 $2 / 3$ 가량은 조직의 장에게 평가결과를 직접 보고하는 것으로 나타났다. 아울러 원조기관들은 기 존의 프로젝트 및 프로그램 단위 사업평가는 물론, 개발주제별 평가, 크로스커팅이슈 평가, 영향력 평가, 분야별평가, 정책 및 전략평가로 평가대상을 넓혀감으로써 원조사업 전반에서 평가를 통한 학습 및 책임성 제고에 노력하고 있다.

10) DAC Evalunet의 "Development Evaluation Resources and Systems" 초안으로 2010.2.10일 Evalunet 정기회의에서 발표된 자료임 


\section{V. 협력단의 평가현황 및 과제}

\section{1. 협력단의 평가역량 및 평가현황}

\section{1) 평가규정 및 정책}

협력단은 1996년 사업평가 전담팀을 설치하며 본격적인 평가활동을 시작했다. 이후 2006년 사업 평가 시행세부지침이 제정되어 평가목적, 평가원칙, 평가기준 및 평가절차를 규정화하였으며, 시행 세칙에 따른 “개발협력사업평가 가이드라인”을 제작해 협력단 내외 평가참여자들이 세칙 및 가이 드라인에 따른 체계적인 평가를 시행하도록 하고 있다.

\section{〈Box4〉 협력단 평가목적, 원칙, 기준 및 대상}

· 평가목적 : 학습 및 책임성 확보

· 평가원칙 : 공정성, 독립성, 신뢰성, 유용성, 파트너십

· 평가기준 : 적절성, 효율성, 효과성, 영향력 지속가능성

※ 동 평가기준 외에도 환경 및 여성이 평가에서 고려되도록 하고 있음

· 평가대상 : 프로젝트 및 프로그램, 정책, 분야, 국가, 주제, 형태 등

협력단은 평가가 원조사업 책임성확보를 위한 주요 수단임을 인식하고, 평가를 통해 도출된 결과 및 사업성과를 발간물 및 홈페이지 등 다양한 매체를 통해 공개하고 있다. 아울러 내부적 학습효과 를 높이기 위해 평가결과의 피드백을 강화하고 있는데, 2008년부터 평가결과 활용 시스템을 구축 해 운영중이다. 이 시스템에서는 사업평가실이 전년도 평가결과에서 도출된 교훈 및 제언사항들을 차년도 과제로 선정해 담당부서에서 이행하도록 하고 그 결과를 모니터링하고 있다.

또한 협력단은 평가의 파트너십 원칙에 따라 다양한 이해관계자(사업담당자, 수원국정부 및 수혜자 등)가 평가에 참여하도록 장려하고 있으며, ${ }^{11)}$ 주요 평가를 용역을 통한 외부평가로 실시함으로써 평가에서의 공정성과 객관성을 높이고자 노력하고 있다. 아울러 사업평가실은 평가방법을 지속적 으로 개발 및 개선해오고 있는데, 2009년도에는 '프로젝트 기획, 모니터링 및 평가방법론'을 발간 하였으며, 2010년도에는 '수혜자평가' 방법을 개선중이다. 


\section{2) 평가체계}

사업평가실은 조직적으로 이사(지역정책, 정책연구, 평가 총괄) 산하에 위치해 있다. 사업평가실은 연간평가계획을 수립해 이행하며, 평가관련 지침, 가이드라인, 매뉴얼 등을 제작하거나 개정하며 직원들의 평가활동을 지원한다. 협력단의 평가는 크게 두가지로 나뉘는데, 사업평가실에서 추진하 는 평가와 사업부서별로 자체 실시되는 평가이다. 사업부서(프로젝트 사업, 봉사단파견사업, 연수 생초청사업 등)는 개별사업의 중간 및 종료평가를 자체 실시하고 그 결과를 사업평가실에 보고하고 있다.

사업평가실은 협력단이 추진하는 사업의 사후평가(사업종료후 1 년이 경과한 사업에 대해 실시하는 평가)를 통해 사업의 효과성, 영향력, 지속가능성 등을 종합검토하고 있다. 아울러 협력단의 개발 협력 정책 및 전략에 대한 평가를 실시하고, 보건, 의료 등 주제별 또는 분야별 평가를 실시하고 있 다. 또한 협력대상국별 평가를 실시하여 특정 국가에 대한 지원전략 및 개발사업의 효과성을 평가 하고 있으며, 사업유형별(프로젝트, 봉사단파견사업, 연수생초청사업 등) 타당성 및 효과성을 평가 하기도 한다.

사업평가실은 평가결과를 담당이사를 거쳐 이사장에게 보고하며, 평가를 통해 도출된 제언사항 및 교훈을 정리해 피드백을 추진한다. 2010년부터는 여타 국내 원조기관과 마찬가지로 평가계획, 평 가결과, 피드백결과를 국제개발협력위원회 산하 통합평가소위원회에 보고하게 된다. 


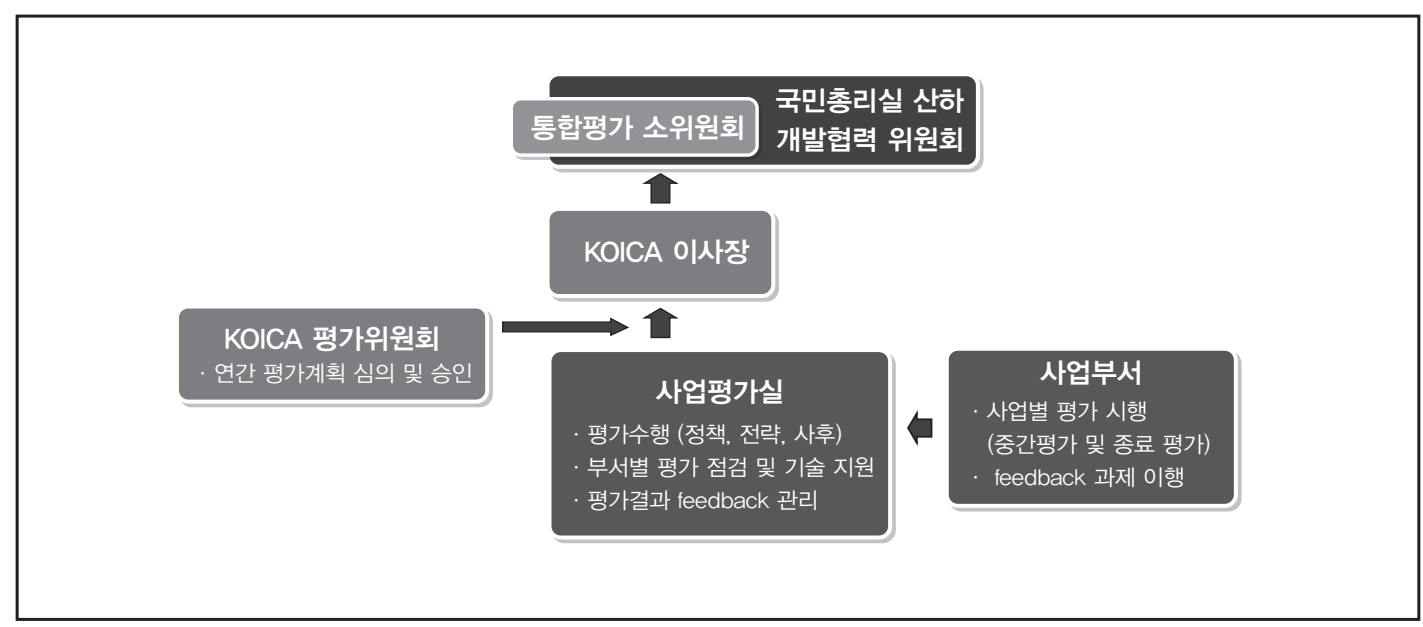

\section{〈Box5〉 통합평가 소위원회}

무유상 원조사업의 정책일관성 및 조화 강화 방안의 일환으로 2009년 국제개발협력위원회(의장: 국무총리) 산하 통합평가소위원회가 구성되었다. 소위는 2009년 통합평가지침 등 관련체제를 구 축해 2010년부터 통합평가를 시범 실시중이며, 이 지침에 따라 협력단을 포함한 원조수행기관은 매년 초 연간평가계획을 수립해 소위에 보고하고, 매년 10월까지 평가결과를, 12 월까지 피드백 결과를 보고해야 한다.

\section{3) 평가예산 및 인력}

협력단의 평가예산은 2010년도 기준 약 8억원으로 전체 협력단 예산의 $0.19 \%$ 가량을 차지한다. 2009년 기준 선진국 평균은 약 30억원으로 전체예산 대비 $0.15 \%$ 를 차지한다. 사업평가실에는 실 장을 포함 총 6 명의 평가담당 인력이 근무중이다.

협력단은 직원들의 평가역량 강화를 위해 평가교육을을 지속적으로 실시해오고 있다. 2009년도에 는 논리모형(Logical Framework) 및 성과중심관리(RBM) 교육을 실시했으며, 2010년도에도 유사 한 교육이 실시될 예정이다. 또한 ODA 교육원에서는 일반인 및 협력사업 외부 관계자 대상 모니터 링 및 평가수행자교육을 분기별로 실시하고 있다. 


\section{4) 평가 파트너쉽}

평가에서의 파트너십을 강조하는 국제사회의 동향에 맞추어, 협력단은 평가에서 여타 공여국 및 수원국과의 파트너십을 강화하고 있다. 2009년도에는 독일의 대외기술협력단(Gesellschaft für Technische Zusammenarbeit, GTZ)과 라오스에서 수행된 직업훈련교육 사업에 대한 공동평가를 시행하였다. 또한 평가에서 수원국의 평가시스템 및 평가역량을 최대한 활용할 수 있도록 2009년 도부터 일부 평가에서 현지워크샵을 시행중이며 2010년도에는 더욱 확대될 예정이다.

또한 협력단은 DAC 가입을 계기로 2010년도부터 Evalunet 활동을 본격적으로 시작했다. Evalunet은 평가관련 각종 기준을 개발하는 동시에 회원국간 다양한 평가정보(공여국별 평가계획 및 평가결과보고서 등)가 공유되는 네트워크로서, 협력단은 Evalunet 활동을 통해 평가에서 다양 한 파트너십 기회를 모색할 예정이다.

\section{2. 협력단 평가과제}

\section{1) 사업기획 단계에서 평가에 대한 고려 미흡}

협력단의 평가에서 가장 우선적으로 해결해야 할 문제는 사업기획 단계에서 평가에 대한 고려가 미 흡하다는 부분이다. 효과적인 모니터링 및 평가수행을 위해서는 사업기획시 명확한 사업목표가 수 립되고, 이것을 측정할 수 있는 지표가 개발되어야 한다. 협력단 프로젝트 사업의 경우 프로젝트 설 계 매트릭스(Project Design Matrix, PDM)가 활용되고 있고 이 매트릭스를 통해 사업목표수립, 투입/산출물 결정, 지표개발, 프로젝트 수행시 예측되는 위험요소를 파악해 사업을 기획하도록 하 고 있다. 하지만 $\mathrm{PDM}$ 에 작성된 내용들이 실제 모니터링 및 평가에 활용되는 경우는 드문데, 이것 은 $\mathrm{PDM}$ 의 내용이 충분한 조사를 통해 작성되지 못하기 때문이다. 프로젝트 담당직원들은 연평균 5.6 개의 프로젝트(2010년 기준)를 운용하고 있어 업무량이 과중하고, 사업기획은 1-2주간의 실시 협의를 포함해 단기간에 이루어진다. 때문에 실제로 모니터링 및 평가까지 고려해 사업을 기획하기 어려운 현실이다. 


\section{2) 투입/산출물 위주의 사업관리 및 평가}

또 다른 문제점은 평가가 투입물과 산출물 위주로 이루어진다는 것이다. 예를 들어 프로젝트사업의 경우 건축 및 물자지원 이행현황, 예산집행률 등을 중심으로 사업을 모니터링하고 관리하고 있다. 봉사단파견사업 또한 파견인원 목표달성률 위주로 사업성과가 관리되어 왔다. 사업관리 및 평가가 실제 빈곤감소 및 개발에 미치는 효과를 측정하는 수준으로 발전하지 못한 이유는 협력단이 아직 성과중심관리 시스템을 완전히 도입하지 못한 문제에서 찾을 수 있다. 하지만 더 근본적으로는 국 내적으로 개발원조에 대한 인식이 낮아 원조기관의 책임성을 개발효과성으로까지 확대시키지 않아 왔으며, 이러한 외부환경에서 원조기관은 공공기관으로서 행정적 임무(예산집행 및 연간사업이행) 에 우선 집중해 왔다는 점에서 원인을 찾을 수 있다.

\section{3) 제한적 평가방법의 사용}

아울러 협력단의 평가가 그동안 정성적 평가에 치우쳐왔다는 문제가 있다. 평가자들은 제한된 여건 속에서도 가능한 다양한 평가방법(문헌조사, 인터뷰, 설문조사, 현지조사 등)을 활용하고자 노력해 왔으나, 실제 개발사업 이행을 통한 빈곤 및 개발지표의 변화를 정량적으로 조사하고 평가하는 데 에는 어려움이 있었다. 이것은 앞서 제기한 두가지 문제--사업기획단계에서 평가가 고려되지 않 고, 사업관리 및 보고체계가 투입/산출물 위주로 되어 있는 것--와 연관된다. 즉 사업기획에서 달 성해야 할 목표치가 명확히 책정되지 않고, 기준치(Baseline)가 조사되지 않은 경우가 많아서, 평 가시점에서 정량적인 조사를 시작하기가 어려운 것이다. 정성적 평가는 물론 다양한 장점이 있지만 정량적 평가가 완전히 배제됨으로써 평가의 객관성 확보 문제로 이어질 수 있다.

\section{4) 평가 전문인력의 부족}

협력단 평가에서 마지막으로 제기되는 문제는 협력단 외부에 평가전문기관 및 인력이 부족하다는 점이다. 협력단 사업평가실은 평가의 객관성 확보를 위해 외부평가를 계속 확대하고 있으며, 2009 년에는 전체 9건 중 5건이 외부평가로 추진되었고, 2010년에는 7 개 평가건 전체가 외부평가로 추 진될 예정이다. 그러나 2006년 이후 사업평가실 평가 외주용역 입찰에 참여한 기관은 약 20개 기 관 수준으로, 그 중 제안서 심사 등 경쟁을 통해 실제 평가에 참여한 기관은 지난 5 년간 11 개 ${ }^{12)}$ 에 불과해, 실제로 다양한 평가종류 및 분야에 비해 외부기관 풀이 부족한 실정이다. 외부 평가기관 및 인력이 부족한 이유는 우선 국내적으로 개발협력 사업에 대한 인식이 낮아 이에 따른 개발분야 전 문인력이 부족하기 때문이며, 아울러 개발협력평가의 경우 해당 개발분야에 대한 전문지식과 함께

12 ) 대외경제정책연구원, 명지전문대학 산학협력단, (사)한국국제개발연구소, (사)한국개발전략연구소, 서울대학교 행정대 학원, 시너지비전, (주)한국전산감리원 전략기획팀, 한경대학교 개도국기술협력연구소, 한국능률협회컨설팅, 한국환경 정책 평가연구원, 한성대학교 산학협력단 
평가에 대한 지식 및 경험을 가진 양분야 전문가(Dual professional)가 요구되기 때문이다.

\section{3. 향후 평가 개선방향}

앞서 제기한 평가의 문제점을 개선하기 위한 가장 이상적인 해결책은 협력단 조직 차원에서 성과중 심관리체계를 도입하는 것이다. 설명한 바와 같이 평가의 어려움과 문제점은 비단 평가단계에서만 발생하는 것이 아니라 사업단계 전반에서 영향을 받고 있기 때문이다. 그러나 성과중심관리체계의 도입은 조직구조, 업무절차, 예산, 인력 전반에 대한 대대적인 개선이 필요한 작업이며, 내외부 여 건을 감안할 때 단시간내에 추진되기는 힘들다. 따라서 협력단의 평가 강화를 위해서는 가장 시급 한 문제에 대해 현실적인 대안을 찾는 방안이 필요할 것이다.

우선, 전략, 프로그램, 프로젝트의 기획 단계에서 모니터링 및 평가에 대한 고려를 강화해야 한다. 협력단이 현재 개선중인 국별지원전략(Country Assistance Strategy, CAS) 및 전략에 따라 개발 될 프로그램, 프로젝트의 계획에는 가능한 범위에서 지표, 모니터링 및 평가계획(자료수집 및 분석 방법 포함)이 포함되어야 한다. 이러한 노력은 모니터링 및 평가단계에서 평가자에 의한 주관적인 성과 정의 및 평가를 방지해 평가의 객관성 확보에 기여할 것이다.

평가방법적인 측면에서는, 필요한 부분에서 정량평가를 점차 확대하되, 모든 전략 및 사업에 정량 적인 평가를 시행할 필요는 없으며 또한 현실적으로 불가능하므로, 현재 사용 중인 평가방법(문헌 조사, 인터뷰, 설문조사, 현지조사 등)의 심도를 높이는 방안을 함께 추진해야 할 것이다. 특히 수 원국에 대한 조사가 그동안 수원국 정부에 치우쳐왔던 점을 개선해 수혜자에 대한 조사 및 인터뷰 를 확대해야 한다.

아울러 평가결과의 활용을 강화해야 한다. 협력단은 현재 평가결과 활용 시스템을 운영 중이며, 평 가결과 활용 실적을 부서 및 개별직원의 업무평가에 반영하는 방안을 검토 중이다. 평가결과의 피 드백은 이러한 규정화 작업과 함께, 기관장 및 관리자들이 지속적인 관심을 보이고 직원업무 수행 에서 우선순위를 둠으로써 더욱 원활하게 추진될 수 있을 것이다. 아울러 평가결과의 활용도를 높 임으로써, 사업수행자들은 다시 평가의 중요성을 인식하고, 사업기획 및 관리에서 평가에 대한 고 려를 강화하고, 평가에도 보다 적극적으로 참여하게 될 것이다.

또한, 평가 이해관계자의 역량강화를 위한 지속적인 교육과 매뉴얼 개발이 필요하다. 평가자는 개 발협력사업에 대한 이해, 평가대상 분야(sector)에 대한 전문지식, 평가방법에 대한 지식 및 경험 이 필요하다. 하지만 평가에 참여하는 협력단 직원 및 외부컨설턴트가 필요한 모든 요건을 충족하 
는 경우가 드물다. 협력단 직원의 경우 평가방법에 대한 지식이, 외부 컨설턴트의 경우 개발협력사 업 및 지역에 대한 지식이 부족한 경우가 많다. 따라서 대상자별 필요한 부분에 대한 수요를 파악하 여, 평가매뉴얼 개발 및 교육을 강화해야 할 것이다.

마지막으로 Evalunet, MOPAN과 같은 국제적인 평가모임에 더욱 적극적으로 참여함으로써 선진 국들의 평가경험 및 평가방법을 학습하고, 아울러 우리 평가결과를 공유함으로써 평가의 투명성 확 보에 기여할 수 있을 것이다. 


\section{참고문헌}

\section{1. 국내문헌}

국제협력단, 『사업관리자를 위한 개발협력사업평가 가이드라인』 (성남: 한국국제 협력단, 2008)

국제협력단, 『논리모형기획 및 성과중심관리(LFA/RBM) 교육결과보고서』(성남: 한국국제협력단, 2008)

\section{2. 국외문헌}

Basil Edward Cracknell, Evaluating Development Aid: Issues, problems and solutions (New Delhi: Sage Publication India Pvt Ltd, 2000)

Jody Zall Kusek and Ray C. Rist. Ten Steps to a Results-Based Monitoring and Evaluation System (Washington, DC.: The World Bank, 2004)

OECD/DAC, "Results Based Management In The Development Cooperation Agencies: A Review of Experience," (Paris: OECD/DAC, 2001)

OECD/DAC. "Principles for Evaluation of Development Assistance," (Paris: OECD/DAC, 1991)

\section{3. 인터넷 자료}
www.adb.org
www.koica.go.kr
www.oecd.org
www.worldbank.org 